\title{
Mechanisms of state support implementation of the project to create a cluster in Russia using the example of the water supply and wastewater disposal cluster in St. Petersburg
}

\author{
Victoria Holodkova ${ }^{1, *}$ Angela Mottaeva $^{2}$, and Tatyana Pokrovskaya ${ }^{3,4}$ \\ ${ }^{1}$ Saint-Petersburg State University, 62, Chaikovskogo street, 191123, Saint Petersburg, Russia \\ ${ }^{2}$ Moscow Region State University, 10A, Radio str, 105005, Moscow, Russia \\ ${ }^{3}$ Moscow Polytechnic University, Bolshaya Semenovskaya str., 38, 107023, Moscow, Russia \\ ${ }^{4}$ Moscow Financial Industrial University" Synergy, Izmailovsky Val, 2, 105318, Moscow, Russia
}

\begin{abstract}
The article presents the mechanism and scheme of creating a cluster of water supply and wastewater disposal in St. Petersburg. The developed and approved Concept of water supply and wastewater disposal cluster of St. Petersburg, which includes three segments: educational, technological and industrial, is presented in detail. The educational segment is represented by the Water Academy and other educational institutions - partners of the Cluster. The technology segment includes demonstration, exhibition, engineering and consulting centers. The industrial segment consists of companies-suppliers of materials and equipment for the sphere of water supply and wastewater disposal sector of St. Petersburg and companies that plan to organize production in St. Petersburg. Each of the segments performs its specific functions and tasks. The main ways of development and long-term tasks of the Cluster are outlined.
\end{abstract}

\section{Introduction}

State support of the innovation cluster in Russia can be divided into several types.

First, it is necessary to consider the support of innovation activities of the cluster as a priority. The concept of creating a cluster provides for the creation of a Technopark. The main objective of the Technopark will be innovation.

The current Federal legislation provides for co-financing of the activities of the subjects of the Russian Federation to create technoparks in the field of high technologies $[1,2]$.

Subsidies are provided for co-financing of expenditure obligations of budgets of subjects of the Russian Federation on construction of objects (part of objects) of Technopark in the sphere of high technologies (further - Technopark), reconstruction of object (part of object) of Technopark, including on creation of objects of engineering networks, the street and road network and improvement which are included in the project of

\footnotetext{
* Corresponding author: holodkova@yandex.ru
} 
construction (reconstruction) of object (part of object) of Technopark and which are technologically connected with object of construction (reconstruction).

The procedure for granting subsidies from the Federal budget is established for 20132014 by the decree of the Government of the Russian Federation dated 22.07.2013 № 616, as well as by the order of the Ministry of communications of 26.07.2013 № 187. For the next years the order isn't established now $[3,4]$.

This subsidy is provided to the organization engaged in the construction of the infrastructure of the Technopark, which will be one of the projects of the cluster [5].

\section{Methods}

In 2015 , a project to create a water supply and wastewater disposal cluster was presented in St. Petersburg (to the investment Council under the Governor) and the Concept of promoting the formation and development of the cluster was approved (Resolution of the Government of St. Petersburg dated April 13, 2015 No. 350 "On approving the Concept of promoting the formation and development of the water supply and wastewater disposal cluster of St. Petersburg"). During 2015-2016 the working group under the leadership of the Vice-Governor O. A. Markov and with the participation of the Committee on investments, the Committee on energy and engineering, the Committee on industrial policy and innovation, as well as the management of Vodokanal, active work was carried out on the development of the cluster [6].

Table 1. Structure of Water cluster.

\begin{tabular}{|c|c|c|}
\hline \multicolumn{2}{|c|}{ Water cluster } \\
\hline Educational segment the & Technological segment & Industrial segment \\
\hline $\begin{array}{c}\text { Water Academy } \\
\text { Partner educational } \\
\text { institutions }\end{array}$ & Engineering center & $\begin{array}{c}\text { Manufacturers of materials and } \\
\text { equipment - members of the } \\
\text { Cluster }\end{array}$ \\
\hline & Consulting center & \\
\hline
\end{tabular}

Within the framework of the developed and approved concept, the water supply and wastewater disposal cluster of St. Petersburg includes three segments: educational, technological and industrial.

The educational segment is represented in Water Academy and other educational institutions - partners of the cluster. The technology segment includes Demonstration and exhibition, Engineering (established by Vodokanal in October 2016) and Consulting centers. The industrial segment consists of the companies - suppliers of materials and equipment for the sphere of VKH of St. Petersburg and the companies which plan to organize production in St. Petersburg. Each of these segments performs its specific functions and tasks [7].

In order to carry out research, scientific and technical activities and innovation. A Water Academy will be created within the cluster. This structure can also receive a subsidy from the budget of St. Petersburg. 
Article 78 of the Budget code of the Russian Federation provides for the possibility of providing subsidies to legal entities, individual entrepreneurs, as well as individuals producers of goods, works, services on a gratuitous and irrevocable basis in order to compensate for lost income and (or) financial security (compensation) costs in connection with the production (sale) of goods (except excisable goods, except cars and motorcycles), performance of work, provision of services. Cases and the order of providing subsidies are established by the law of the subject of the Russian Federation.

According to article 24 of the Law of St. Petersburg of 27.11.2013 No. 654-102 "On the budget of St. Petersburg for 2014 and for the planning period of 2015 and 2016" the Government of St. Petersburg in the course of execution of the budget of St. Petersburg defines conditions and the order of providing subsidies from the budget of St. Petersburg provided according to article 78 of the Budget code of the Russian Federation, including at the expense of means of reserve Fund of the Government of St. Petersburg and interbudget transfers, coming to the budget of St. Petersburg from the Federal budget and state extrabudgetary funds.

The size of subsidies from the budget of St. Petersburg provided according to article 78, point 2 of article 78.1 of the Budget code of the Russian Federation to the specific recipients specified in the name of target articles of Departmental structure of expenses of the budget of St. Petersburg for 2014 is defined proceeding from expenses in connection with production (realization) of goods (except for excise goods), performance of works, rendering services and implementation of the established types of activity which financial security (compensation) is performed at the expense of means of subsidies from the budget of St. Petersburg, and within the limits of the budgetary appropriations provided by the corresponding target article.

Scientific and innovative activities provide for the possibility of state support in the form of subsidies.

In St. Petersburg there is a St. Petersburg Law dated 12.10.2009 No. 411-85 "About fundamentals of the scientific-technical policy of Saint-Petersburg", the resolution of the Government of St. Petersburg dated 28.06.2011 № 835 "About the Complex program "Science. Industry. Innovation" in St. Petersburg for 2012-2015" (hereinafter - the Comprehensive program).

The comprehensive program approved a program of activities to support scientific and technical organizations in the form of grants.

If it is necessary to significantly finance the costs of the Water Academy, it is possible to consider the option of including this funding in the budget of St. Petersburg for the corresponding financial year and in the Comprehensive program "Science. Industry. Innovation" as a separate line of subsidies to the Water Academy for reimbursement of costs.

Water Academy was established in 2015. The Academy is located in the heart of St. Petersburg. It is a modern training center for 400 people with multimedia equipment, 12 spacious classrooms, a library and a conference room.

In February 2016, the Committee on education of the government of St. Petersburg issued a license to the Water Academy and opened a set of seven short-term training programs (table 1).

The programs are designed for engineers and technicians of urban enterprises, employees of design organizations and equipment manufacturers. The average number of groups for additional professional programs is from 10 to 15 people. At the end of each program, all those who have been trained are issued a document of the state sample. In 2016, more than 150 people were trained under the programs of the Water Academy. Among the students of the Academy - specialists of Russia, vodokanals and industrial 
enterprises: the state unitary enterprise "St. Petersburg Vodokanal", MUP "Lipetsk aeration station", LLC "Chelnyvodokanal", OOO "Rosenergo", etc [8,9].

Table 2. The training programmes presented in the Aquatic Academy.

\begin{tabular}{|l|c|}
\hline \multicolumn{1}{|c|}{ Program title } & $\begin{array}{c}\text { Program Scope, } \\
\text { academic hour }\end{array}$ \\
\hline Creation of hydraulic models of water supply network & 24 \\
\hline Geographic information system - based management utility & 36 \\
\hline $\begin{array}{l}\text { Metrological support of production in the provision of water supply } \\
\text { and sanitation services }\end{array}$ & 40 \\
\hline Upgrading and improving the efficiency of treatment facilities & 16 \\
\hline Management system of the enterprise & 16 \\
\hline $\begin{array}{l}\text { Chemical balance at the enterprises of VKH - the basis of quality } \\
\text { management of wastewater treatment and interaction with subscribers }\end{array}$ & 36 \\
\hline $\begin{array}{l}\text { The introduction and maintenance of functioning of system of labor } \\
\text { protection management and industrial safety in utilities }\end{array}$ & 16 \\
\hline
\end{tabular}

The following promising programs are under development:

- advanced training for specialists in the operation of water bodies of urban infrastructure;

- training direction "assessment and design for water supply and sanitation sector»;

- long-term educational program of professional retraining (more than 572 academic hours) for heads of enterprises of the industry.

In the near future also include the introduction of distance learning. In addition, the Academy actively cooperates with the Russian Association of water supply and sanitation, College of water resources, International center of advanced water technologies, interregional resource center. In 2016, three seminars were held, in which 160 Russian and foreign specialists of the industry took part.

Among the international partners of the Academy are ladec and Veolia, Milan Vodokanal, Engineering Institute of the University of nice-Sofia-Antipolis. Currently, negotiations are underway on the implementation of an educational project with the participation Of the Association of organizations of HQ "Aqua-Bel" in the Republic of Belarus. This international partnership will improve the effectiveness of training by incorporating international experience in the field of water supply and wastewater disposal, making The water Academy programs unique.

The priority plans for the development of the Water Academy programs include the training of industry leaders for long-term professional retraining programs (the planned start date of training is September 1, 2017). In addition, in 2018 it is planned to study under the program of applied bachelor. Graduates of the programs will receive state diplomas and will be in demand at the enterprises of municipal economy as process engineers, specialists of production and technical services, masters in the operation of facilities.

Within the technological segment, all participants of the cluster engaged in innovation and research activities receive the following benefits:

1. Exemption from VAT in the implementation of research and development work. This exemption is granted for the following research and development ( $\mathrm{R} \& \mathrm{~d}$ ) activities):

- relating to the creation of new or improvement of existing products and technologies, provided that the following activities are carried out as part of R \& d (sub-activities). 16.1 clause 3 article 149 of NK of the Russian Federation):

- design of an engineering facility or technical system;

- development of new technologies;

- creation of prototypes of machines, equipment, materials not intended for sale to third parties, their testing; 
- carried out by educational institutions and scientific organizations on the basis of economic contracts (podp. 16 clause 3 , article 149 of the tax code);

- carried out at the expense of budgets and specified in the tax code of special funds (podp. 16 p. 3 Art. 149 of the tax code).

At the same time, the taxpayer has the right to refuse the application of this benefit.

2. Exemption from VAT on the exercise of rights to intellectual property. Thus, the implementation of exclusive rights to inventions, utility models, industrial designs, computer programs, databases, topology of integrated circuits, secrets of production (knowhow), as well as the rights to use these results of intellectual activity on the basis of a license agreement (subp. 26 p. 2 Art. 149 of the tax code). Thus the taxpayer has no right to refuse use of the specified release.

It should be noted that the sale of tangible media with software in a commodity package containing the terms of the license agreement is not exempt from VAT, because in fact the license agreement will be concluded by the user later by entering the registration data on the official website.

Also not exempt from VAT execution of works on the creation or modification of computer programs under the contract, as well as the provision of information, services and technical services related to the use of the transferred rights.

3. Benefits in accounting for R\&D costs. According to paragraph 2 of Art. 262 of the tax code, the costs of certain types of R\&D (including those that did not give a positive result) are subject to tax accounting at the customer of such works based on the actual amount of expenses with a coefficient of 1.5. Such R\&D should relate to the creation of new or improvement of products (goods, works, services) and be aimed at the development of priority technologies defined by the Government of the Russian Federation. Among the priority technologies mentioned, in particular, nanotechnology, technology of processing, storage, transmission and protection of information, the development of methods of industrial waste management, software production, etc.

4. One-time accounting of expenses for the purchase of electronic computers. In accordance with paragraph 6 . article 259 of the tax code, the taxpayer has the right to take into account the cost of acquisition of electronic computer equipment as part of material costs in full as it is put into operation subject to the following conditions:

- the organization carries out activity in the field of information technologies, i.e. is engaged in development and implementation of programs for computers, databases on the material carrier or in electronic form on communication channels irrespective of the type of the contract, and (or) renders services (performs works) on development, adaptation, modification, testing and maintenance of programs for computers, databases;

- the organization received the document on the state accreditation of the organization performing activity in the field of information technologies in the order established by the legislation (the order of the Government of the Russian Federation of 06.11.2007 N 758 "Regulations on the state accreditation of the organizations performing activity in the field of information technologies");

- the share of income from activities in the field of information technology at the end of the reporting (tax) period is not less than $90 \%$ of the total income of the organization for the period, including from foreign persons - not less than $70 \%$;

- the average number of employees for the reporting (tax) period is not less than 50 people.

At the same time, the above conditions must be met simultaneously.

5. Accelerated depreciation of fixed assets used in scientific and technical activities. Thus, according to the PP. 2 p. 2 article. 259.3 of the tax code, the depreciation of fixed assets used exclusively for scientific and technical activities, the company has the right to apply to the basic depreciation rate of a special coefficient not higher than 3 . 
6. Investment tax credit. According to Art. 67 of the tax code, an investment tax credit is a form of deferred income tax (as well as regional and local taxes) for up to five years on the terms of repayment of the loan and accrued interest (at a rate of not more than 3/4 of the refinancing rate of the Central Bank of the Russian Federation) (art. The investment credit can be provided including to the organizations performing:

- implementation or innovative activity, including for creation of new or improvement of the applied technologies, creation of new types of raw materials or materials, - for the amount determined by the agreement between authorized body and the organization;

- R \& d or technical re-equipment of own production, as well as investments in the creation of energy-efficient facilities - for an amount not exceeding $30 \%$ of the cost of purchased equipment used exclusively for these purposes.

In fact, the work of the technology segment began with the creation of the Cluster in April 2015.

The opening of the Demonstration and exhibition center took place on the territory of the Northern aeration station in the village of Olgino on November 6, 2015 with the participation of the Governor and Vice-governors of St. Petersburg.

The demonstration and exhibition center is a platform for interaction of producers and consumers of products of municipal economy, demonstration of technologies and development of enterprises, as well as exchange of experience, testing of equipment and testing.

On the territory of the Demonstration and exhibition center, two sites are organized: the first one presents technological and metrological equipment, composite materials, control and safety systems, shut-off and control valves, installations of trenchless pipe laying, gas cleaning systems; the second - pipe products, pumping equipment, surface runoff treatment facilities, complete pumping stations, wells, reinforced concrete products.

The Demonstration and exhibition center presents expositions of more than a hundred companies whose products are used at the facilities of sue "Vodokanal of St. Petersburg". Displayed at the exhibition: equipment for water treatment plants and sewage treatment plants, tubular goods, reagents, valves, pump and instrumentation, automation system.

The main feature of the Demonstration and exhibition center of the cluster is that it is not just an exhibition of products, but existing technological complexes. For example, here you can see how the macerator copes with major pollution, how the complete mechanical cleaning unit works, how different operating conditions (pressure, flow, etc.) are modeled on models of hydraulic systems, how the shut-off and control valves work.

Demonstration and exhibition center of the Cluster is used to develop skills in the operation of equipment of domestic production in the field of HQ for industry professionals and University students. Here is created and operates the only in Russia test stand for nonpressure flows, designed to determine the actual error of measuring the level, speed, flow and volume of liquid under different operating conditions (low costs, counterclones, etc.). Currently, most of these devices are tested separately by level, separately by flow rate. This stand allows to carry out tests in a complex, including full-pass measuring instruments. Thanks to the work of the centre, more than 40 sets of technical documentation and equipment are currently under review and pilot testing.

\section{Results}

The cluster together with sue "Vodokanal of St. Petersburg" provides information support of the Demonstration and exhibition center. Since its inception, it has been visited by: Russian and foreign delegations (Tatarstan, Belarus, Kazakhstan, Japan, etc.); participants of industry forums ("Green economy"); participants of industry conferences (Russian 
Association of water supply and sanitation); participants of thematic seminars ("Effective methods of reconstruction of networks"); water utilities.

The engineering center of the water supply and wastewater disposal Cluster of St. Petersburg was established in October 2016. Its main objectives are: promotion and replication of the industry's competence; development of import-substituting technologies and equipment; creation of effective domestic production of equipment and materials in the region; formation of a portfolio of ready-made technological solutions [10].

Currently, the Engineering center has a portfolio of ready-made solutions. They are based on modern technologies that have been tested and successfully used at water supply and wastewater disposal facilities of sue "Vodokanal of St. Petersburg". In addition, a portfolio of promising own developments of the Engineering center has been formed, which is planned to be implemented in 2017-2018.

The engineering center plans to develop the export potential of Russian enterprises. Activities in this area have already been started and are being worked out within the framework of cooperation agreements between St. Petersburg and Belarus, Kazakhstan, India, Bahrain, Cyprus. A list of partners for the execution of projects in the field of technological engineering, research, technology and innovation, as well as in the field of expertise and standardization [11].

The task of ensuring the promotion of industry competence and project support will be taken over by the Consulting center, which was established in December 2016. It will be engaged in property,legal and financial support, market research, preparation and support of projects and package solutions.

Within the industrial segment, it is also possible to provide grants from the regional budget to the cluster participants.

Article 4 of the Law of St. Petersburg dated 16.11.2001 № 752-97 "On grants of St. Petersburg in the field of scientific and technical activities" provides for the provision of grants in several areas including:

- materials;

- ecology.

Provision of grants of St. Petersburg in the field of scientific and technical activities in the form of subsidies is also provided for in paragraph 4.2.2 of the Decree of the Government of St. Petersburg dated 28.06.2011 № 835 "On the Comprehensive program "Science. Industry. Innovations" in St. Petersburg for 2012-2015».

Subsidies referred to in paragraph 4.2.2 are provided to individuals and legal entities, recognized winners of the competition for the grants of St. Petersburg in the field of scientific and(or) scientific and technical activities (hereinafter - grants) carried out in the manner prescribed in the regulations on the conditions and order of granting of grants of St. Petersburg in the sphere of scientific and scientific-technical activities, approved by the decree of the Government of St. Petersburg dated 01.04.2008 № 319 "About measures for implementation of the Law of St. Petersburg "On grants of St. Petersburg in the sphere of scientific and scientific-technical activities", on a gratuitous and irrevocable basis in order to recover costs or lost revenue in connection with production (realization) of goods, execution of works, providing services in the implementation of scientific and technical activities, experimental development, conducting applied research in the areas of grants specified in the Law of St. Petersburg from 31.10.2001 № 752-97 "On grants of St. Petersburg in the field of scientific and technical activities".

Subsidies are provided based on the results of the competition.

The maximum grant amount is 200 thousand.

The main task of the industrial segment - the organization of production of materials and equipment necessary for the development of the water and wastewater disposal sector, 
in the future - the urban economy. It is planned that this work will be coordinated and conducted by the Engineering center.

The priority project of the industrial segment was a new chemical reagent plant in St. Petersburg. It should be noted that in the region today there is no manufacturer that can fully meet the needs of the city in modern efficient chemicals. The design capacity of the plant will be more than 150 thousand tons/year. It is planned to organize the production of iron sulfate, aluminum sulfate, aluminum hydroxochloride (all - aqueous solution).

The amount of investments in the project announced by the investor will amount to more than 1.1 billion rubles both at the expense of the investor's own funds and at the expense of debt financing. State funding for this project is not provided. Currently, work is underway to provide land for the construction of the plant. Markets for the sale of products have been worked out in detail. The main consumers (about $70 \%$ of products) should be St. Petersburg and Leningrad region [12]. Today the structure of the cluster is fully formed, and it has acquired its functional outlines provided by the Concept [13-19].

\section{Conclusion}

Thus, it can be concluded that preferences in the form of state financing and tax benefits for cluster members are established depending on the type of activity of the organization, but not on territorial or cluster affiliation.

1. It seems appropriate to focus on the following types of benefits and support in attracting legal entities to participate in the activities of the cluster:

2. Low rent for provided office space and land. If the land plot is transferred to the ownership of the cluster (contributed to the authorized capital of the management company), the management company can independently set the rental rate.

3. Assistance in filling out applications and preparation of documents for state orders, subsidies and grants.

4. Providing information on new government orders and grants;

5. A wide range of advice (government orders, marketing and advertising policy, access to foreign markets, project evaluation).

6. Professional training and retraining, professional development of employees of organizations.

7. Reduction of own expenses due to participation in joint cluster projects.

8. Assistance in promotion of products and services to domestic and foreign markets.

9. Conditions for effective interaction with state and local authorities.

\section{References}

1. I.N. Kvasov, A.V. Pivovarova, Financial Analytics: problems and solutions 23, 37-47 (2011)

2. S.N. Kotlyarova, Regional economy: theory and practice 24, 29-39 (2012)

3. M.A. Zobov, Marketing 3, 14-21 (2011)

4. A. Kizyma, Bulletin of the Institute of Economics of the Russian Academy of Sciences 5, 103-110 (2012)

5. A.A. Ivanenko, Bulletin of Samara state University 3, 29-38 (2011)

6. L.D. Gorelik, V.V. Holodkova, Water Magazine 9, 32-33 (2017)

7. E.A. Melnik, L.D. Gorelik, V.V. Holodkova, Water supply and sanitary engineering 1, 8-11 (2017)

8. E.D. Oborina, Economics and entrepreneurship 10-2, 243-249 (2017) 
9. E.D. Ryzhakov, Economic and legal issues 2, 97-101 (2014)

10. V.O. Berdichevskaya, Economics and management 1, 98-103 (2012)

11. I.N. Kvasov, Economic analysis: theory and practice 20, 26-30 (2009)

12. A.A. Medvedev, Education. Science. Scientific personnel 2, 109-111 (2011)

13. E. Ganebnykh, T. Burtseva, A. Petuhova, A.Mottaeva, E3S Web of Conferences 91, 08035 (2019) doi.org/10.1051/e3sconf /20199108035

14. E.I. Markovskaya, A.V. Lusse, A.A. Medved, A.A. Molostova, N.G. Privalov, A.I. Radushinskaya, D.A. Radushinsky, V.V. Holodkova, Mechanisms of public -private partnership. Theory and practice (Ser. Higher education, Moscow, 2019)

15. S.G. Bozhuk, A.S. Krasnov. Proceedings of the 2017 International Conference "Quality Management, Transport and Information Security, Information Technologies", IT and QM and IS 2017. P. 166-172. (2017) DOI: 10.1109/ITMQIS.2017.8085790

16. I. Krasyuk, T. Kirillova, V. Bakharev, B. Lyamin. IOP Conference Series: Materials Science and Engineering, 497, 012125. (2019) DOI: 10.1088/1757899 X/497/1/012125

17. L. Nilova, T. Pilipenko, S. Malyutenkova. Agronomy Research. 15. S2. 1399-1410. (2017) DOI: 10.15159/AR.18.055

18. A. Chernikova, S. Kuzmina, G. Kondrashkova, I. Bondarenkova. Proceedings: IOP Conference Series: Materials Science and Engineering, 497, 012130. (2019) DOI: $10.1088 / 1757-899 \mathrm{X} / 497 / 1 / 012130$

19. V.V. Okrepilov, A.V. Chernikova, A.A. Peshekhonov, I.V. Rudakova. Measurement Techniques. 61. 11. P. 1074-1080. (2019) DOI: 10.1007/s11018-019-01551-y 